\title{
Comparison of plasma and salivary HIV loads determined via a coupling of the Abbott HIV detection system with the DNA Genotek OMNIgene ${ }^{\mathrm{TM}}$ DISCOVER (OM-505) kits
}

\author{
David J Speicher ${ }^{1,2^{*}}$, S Saravanan ${ }^{3}$, N Kumarasamy ${ }^{3}$, K Rangananthan $^{4}$, NW Johnson 1,2,4 \\ From 2nd International Science Symposium on HIV and Infectious Diseases (HIV SCIENCE 2014) \\ Chennai, India. 30 January - 1 February 2014
}

\section{Background}

The DNA Genotek OMNIgene ${ }^{\mathrm{TM}}$ DISCOVER (OM-505) kits are designed to collect and store saliva at room temperature before the extraction and detection of DNA and RNA. Utilizing the OM-505 we determined the HIV salivary viral loads (SVL), which were compared with plasma viral loads (PVL).

\section{Methods}

SVL and PVL were determined on 40 HIV-positive ART naive patients presenting at YRG CARE. Saliva was collected with the OM-505, incubated at $50^{\circ} \mathrm{C}$ for 1 hour. Prior to extraction $70 \mathrm{~mL}$ isopropanol was mixed with 800mL OM-505. From OM-505 and plasma, RNA was extracted automatically on the Abbott m2000sp. HIV loads were determined with the Abbott m2000rt system.

\section{Results}

A calibration curve produced by 10-fold dilutions of HIV virion in HIV negative saliva collected in the OM-505 was linear $\left(R^{2}=0.9951\right)$ from 57,273 to $621 \mathrm{HIV}$ copies $/ \mathrm{mL}$. In clinical isolates, PVL averaged 431,865 HIV copies $/ \mathrm{mL}$ (range: 62 to 7,604,620 HIV copies/mL) whilst SVL averaged 23,267 HIV copies/mL (range: 153 to 220,104 HIV copies $/ \mathrm{mL}$ ). SVL was not detected in 15 samples and could not be determined in 5 samples due to viscosity and cellular debris causing problems during extraction. In 12/17 patients SVL was lower than PVL.

\footnotetext{
* Correspondence: d.speicher@griffith.edu.au

'Molecular Basis of Disease Research Program, Griffith Health Institute, Griffith University, Queensland, Australia

Full list of author information is available at the end of the article
}

\section{Conclusion}

$\mathrm{HIV}$, if present, can be detected accurately in saliva down to $621 \mathrm{HIV}$ copies/mL. SVL does not correlate with PVL and thus cannot be used to accurately determine HIV carriage, but in most cases HIV shedding is low or nonexistent.

\section{Authors' details}

'Molecular Basis of Disease Research Program, Griffith Health Institute, Griffith University, Queensland, Australia. ${ }^{2}$ Population \& Social Health Research Program, Griffith Health Institute, Griffith University, Queensland, Australia. ${ }^{3}$ YR Gaitonde Centre for AIDS Research and Education, Chennai, India. ${ }^{4}$ Ragas Dental College, Chennai, India.

Published: 27 May 2014

doi:10.1186/1471-2334-14-S3-P80

Cite this article as: Speicher et al: Comparison of plasma and salivary HIV loads determined via a coupling of the Abbott HIV detection system with the DNA Genotek OMNIgene ${ }^{\mathrm{TM} T \mathrm{~T}}$ DISCOVER (OM-505) kits. BMC Infectious Diseases 2014 14(Suppl 3):P80.

Submit your next manuscript to BioMed Central and take full advantage of:

- Convenient online submission

- Thorough peer review

- No space constraints or color figure charges

- Immediate publication on acceptance

- Inclusion in PubMed, CAS, Scopus and Google Scholar

- Research which is freely available for redistribution 